\title{
Adsorption and Degradation Behavior of Six Herbicides in Different Agricultural Soils.
}

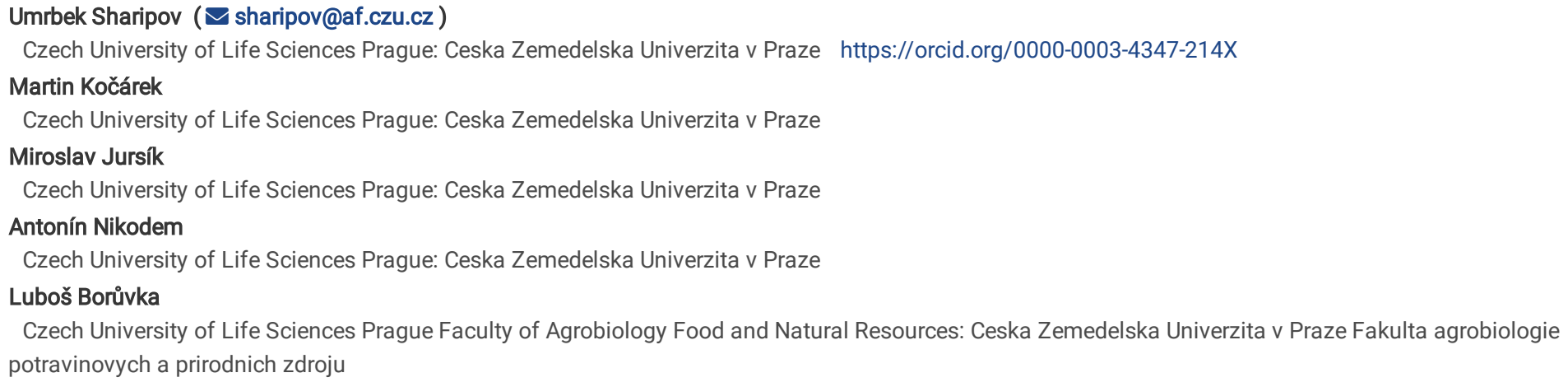

Research Article

Keywords: Dissipation, Sorption, Persistence, Organic matter, Half-life

Posted Date: June 2nd, 2021

DOI: https://doi.org/10.21203/rs.3.rs-529634/v1

License: @ (i) This work is licensed under a Creative Commons Attribution 4.0 International License. Read Full License 


\section{Abstract}

This study focuses on the assessment of herbicide adsorption and degradation in three soils (Haplic Chernozem, Haplic Fluvisol, and Arenic Regozem) from different agricultural regions of the Czech Republic where sunflower is cultivated. Soil samples were used in laboratory batch sorption and degradation experiments for six herbicides commonly used on sunflower crops. The findings are used to examine the effect of soil and herbicide properties on adsorption and degradation, as well as to determine the possible relation between the two processes. The $\left(\mathrm{K}_{\mathrm{f}}\right)$ sorption coefficient ranged from 1.07 to $135.37 \mathrm{~cm}^{3 / \mathrm{n}} \mu \mathrm{g}^{1-}$

${ }^{1 / n} \mathrm{~g}^{-1}$, and sorption increased in order: dimethenamid-p < pethoxamid $<$ s-metolachlor $<$ flurochloridone $<$ aclonifen $<$ pendimethalin. Sorption of all six herbicides was positively correlated with organic matter content $(p<0.001)$, and cation exchange capacity $(p<0.001)$. pH was negatively correlated with the sorption of all six compounds $(p<0.001)$. Degradation rates of herbicides ranged from 0.012 to 0.048 day $^{-1}$, which corresponding to $\left(D T_{50}\right)$ half-lives between 14 - 57 days respectively. The longer half-lives were always found in Haplic Fluvisol with higher organic matter content. Results showed that both adsorption and degradation of herbicides is mainly controlled by soil organic matter. A negative relationship was found between the sorption coefficient and the rate of degradation. It can be concluded that the Freundlich sorption coefficient $\left(\mathrm{K}_{\mathrm{f}}\right)$ can be a good predictor for soil degradation of the studied herbicides.

\section{Introduction}

Soil adsorption and pesticide degradation are the main processes that assess the environmental quality effects of pesticide use (Quintero et al. 2005). Degradation is important for the reduction of soil pesticide residue levels and is divided into the following groups: (i) abiotic or chemical degradation and (ii) biodegradation. Degradation is accompanied by complex processes involving a variety of interactions between soil and pesticide components (Rao et al. 1983; Ainsworth et al. 1993). Several factors, including pesticide physicochemical properties and soil properties (e.g. pH, OM, clay content, and soil texture) are responsible for controlling soil degradation processes (Walker et al. 2001). Climate conditions such as soil water content and temperature, are another factor that influences the rate of degradation. The effect of temperature and soil moisture content on the degradation of herbicides has been extensively investigated (Vischetti et al. 2002; Alletto et al. 2006).

Sorption is one of the major processes affecting pesticide leaching in the subsurface as well as the transport of pesticides in soil. The extent of pesticide sorption in the soil is determined by the composition of the soil and the pesticide (Ainsworth et al. 1993). The most important soil properties that control the extent of pesticide adsorption in the soil are organic matter content (OM) and clay content (Quintero et al. 2005; Hermosin et al. 2006). Many researchers have reported that the function of $\mathrm{OM}$ and clay content is more efficient than a single sorption entity, depending on the level of organic substances that coated the clay content (Stevenson 1972; Hayes 1970). However, other soil properties can play a crucial role, including pH, cation exchange capacity (CEC), and ion strength of soil solution (Ferreira et al. 2001; Spongberg and Ganliang 2000; Kah and Brown 2007). The effects of various soil parameters on the sorption of acidic and basic pesticides have been studied (Kodešová et al. 2011; Gao et al. 1998). Sorption of neutral compounds tends to depend on the OM content of the soil (Spark and Swift 2002). According to Ahmad et al. (2006) in order to determine the sorption of nonionic pesticides, the molecular nature of OM is important. The soil pH influences the pesticide sorption activity and is mainly affected by its acidity (pKa) or base (pKb) constants (Hornsby et al. 1996), and several authors (Kah and Brown 2006, 2007; Hyun et al. 2003) have observed a correlation between ionizable pesticide sorption and soil pH, as the relative quantities of weakly basic and acidic pesticides in ionic form depend on the $\mathrm{pH}$ of the soil system. However, the adsorption of non-ionic molecules by hydrophobic bonding is $\mathrm{pH}$ independent (Weber and Miller 1989).

In this study, six herbicides were examined: pendimethalin, aclonifen, flurochloridone, S-metolachlor, pethoxamid and dimethenamid-p. These herbicides are often used for pre-and post-emergence purposes to control a variety of annual grasses and broad-leaf weeds.

Pendimethalin degradation was previously studied by Ramakrishna et al. (2008) and observed a half-life (DT 50 ) of 90 days in the field. It is usually degraded through photodegradation, volatilization, or biodegradation. Pendimethalin is strongly adsorbed to OM and clay minerals and is therefore slightly mobile in soil (Mohan et al. 2007; PPDB 2019).

Aclonifen is a low water-soluble (1. 4-2.5 $\mathrm{mg} \mathrm{L}^{-1}$ ), non-ionizing herbicide and moderately sorbed on soil components (Gouy et al. 1999). Vischetti et al. (2002) studied sorption and degradation of aclonifen and found low degradation and high soil adsorption.

Flurochloridone persistence was measured in field conditions (Vouzounis and Americanos 1995). It is characterized by low volatility, low soluble in water, and is relatively persistent in soil environments ( Klíčová et al. 2002). Very little is known about flurochloridone adsorption and dissipation in laboratory conditions. However, its toxicological studies in the soil environment have been reported by EFSA (2010).

S-metolachlor sorption was measured by Wu et al. (2011) as with many other hydrophobic and non-ionic herbicides, s-metolachlor has a high affinity for the organic matter fraction of soils and its sorption rate is mainly driven by the organic matter content (Weber et al. 2004). Si et al. (2009) found a significantly negative relationship between $\mathrm{OM}$ and s-metolachlor degradation.

Pethoxamid is known to be non-persistent and moderately soluble in water with low soil adsorption (Jursík et al. 2015; PPDB 2019). Several studies have documented its efficacy and selectivity, as well as soil phytotoxic activity under different moisture conditions (Jursík et al. 2015; Dhareesank et al. 2005). Pose-Juan et al. (2018) were investigated pethoxamid dissipation in amended and unamended soil.

Dimethenamid-p is characterized as having low volatility, high solubility in water, and is non-persistent in soil environments (PPDB 2019). It has a calculated DT $_{50}$ value of about 11.1 days in Haplic Chernozem under field conditions (Kočárek et al. 2018).

The aim of this research was: (i) to characterize the adsorption and degradation of herbicides in three soils concerning different properties; (ii) identify main soil parameters that influence adsorption and degradation employing a correlation analysis, and (iii) to establish how the degradation and sorption processes 
of these herbicides affect each other.

\section{Materials And Methods}

Soils

Three representative soils used in this study were obtained from three different agricultural sites near the sunflower field in the Czech Republic. The soils were sampled from the top layer $(0-20 \mathrm{~cm})$ and used for both sorption and degradation experiments. The selected sites had no history of pesticide treatment in the recent past. The soils were classified as Haplic Chernozem with silty clay loam (Collected in Suchdol), Haplic Fluvisol with loam (in Dobroměrice), and Arenic Regozem with sandy loam (collected in Volárna). Soil profile pictures with descriptions are given in Supporting information, Pictures S1, S2, S3. The physicochemical properties of soils were measured in laboratory conditions and summarized in Table 1.

Table 1

Physical and chemical properties of studied soils in different horizons: $\mathrm{pH}_{\mathrm{H} 2 \mathrm{O}}, \mathrm{pH}_{\mathrm{KCl}}, \mathrm{OM}$ (organic matter content), $\mathrm{CaCO}_{3}$ content, cation exchange capacity $(C E C)$, bulk density $\left(\rho_{d}\right)$, clay, silt, and sand contents.

\begin{tabular}{|c|c|c|c|c|c|c|c|c|c|c|}
\hline Soil type & Location & $\mathrm{pH}_{\mathrm{H} 2 \mathrm{O}}$ & $\mathrm{pH}_{\mathrm{KCl}}$ & $\mathrm{OM}(\%)$ & $\mathrm{CaCO}_{3}(\%)$ & $\mathrm{CEC}\left(\mathrm{mmol}+\mathrm{kg}^{-1}\right)$ & $\rho s\left(\mathrm{gcm}^{-3}\right)$ & Clay (\%) & Silt (\%) & Sand (\%) \\
\hline Haplic Chernozem & Suchdol & 7.914 & 7.131 & 2.63 & 0.57 & 118.99 & 1.72 & 22.49 & 68.57 & 8.94 \\
\hline Haplic Fluvisol & Dobroměřice & 7.796 & 7.320 & 3.45 & 0.93 & 145.62 & 1.71 & 18.5 & 48.9 & 32.6 \\
\hline Arenic Regozem & Volárna & 8.154 & 7.521 & 2.26 & 3.51 & 105.01 & 1.74 & 16.14 & 12.31 & 71.55 \\
\hline
\end{tabular}

Herbicides, other chemicals and analytical techniques

The herbicides with the active ingredient Stomp 400 SC - pendimethalin, Bandur - aclonifen, Racer 25 EC - flurochloridone, Dual Gold 960 EC - Smetolachlor, Successor 600 - pethoxamid, and Outlook - dimethenamid-p were purchased from Sigma-Aldrich with analytical standard purities of 95-99\%. The herbicides have considerably different physicochemical properties (Table 2) and vary in soil sorption (very high and low) and dissipation half-life. Acetonitrile (HPLC Supra-Gradient, purity 99.97\%) and methanol (for pesticide residue analysis, purity 99.9\%) were purchased from Lach-Ner. The conditions and characteristics of the HPLC calibration lines for herbicides are listed in Supporting information Text.S1, and Table S1.

Table 2 Herbicides' water solubility, Freundlich sorption coefficient $\mathrm{K}_{\mathrm{f}}$ and $\mathrm{K}_{\mathrm{foc}}$, half-life $\left(\mathrm{DT}_{50}\right)$ in soil, dissociation constant (pKa).

\begin{tabular}{|c|c|c|c|c|c|c|c|}
\hline Herbicides name & IUPAC name ${ }^{2}$ & Molecular structure $e^{b, c}$ & $\begin{array}{l}\text { Solubility in water } \\
\left(\mathrm{mg} \mathrm{L}^{-1}\right)^{c}\end{array}$ & $(\mathrm{pKa})$ & $\begin{array}{l}\mathrm{K}_{\mathrm{f}}\left(\mathrm{cm}^{3 / \hbar}\right. \\
\left.\mu^{1-1 / 4} \mathrm{~g}^{-1}\right)^{\mathrm{c}}\end{array}$ & $\begin{array}{l}\mathrm{K}_{\mathrm{foc}}\left(\mathrm{cm}^{3 / 4}\right. \\
\left.\mu \mathrm{g}^{1-1 / \mathrm{n}} \mathrm{g}^{-1}\right)^{\mathrm{c}}\end{array}$ & $\begin{array}{l}\mathrm{DT}_{50}(\text { lab), } \\
\text { (days) }^{\circ}\end{array}$ \\
\hline Pendimethalin & $\begin{array}{l}\text { N-(1-ethylpropyl)-2,6-dinitro-3,4- } \\
\text { xylidine }\end{array}$ & & 0.33 & $\begin{array}{c}2.8^{2} \text { (strong acid) } \\
10.94^{\mathrm{d}} \text { (strongest acidic) } \\
-1^{\mathrm{d}} \text { (strongest basic) }\end{array}$ & 220.1 & 13792 & 182.3 \\
\hline Aclonifen & $\begin{array}{l}\text { 2-chloro-6-nitro-3- } \\
\text { phenoxyaniline }\end{array}$ & & 1.4 & $-3.15^{\circ}$ (very strong acid) & 138.1 & 7126 & 62.3 \\
\hline Flurochloridone & $\begin{array}{l}\text { 3-chloro-4-(chloromethyl)-1-[3- } \\
\text { (trifluoromethyl) phenyl]-2- } \\
\text { pyrrolidinone }\end{array}$ & & 21.9 & No dissociation a & 9.4 & 700 & 53 \\
\hline S-Metolachlor & $\begin{array}{c}\text { 2-chloro-N-(2-ethyl-6- } \\
\text { methylphenyl)-N-((1S)-2- } \\
\text { methoxy-1-methylethyl) } \\
\text { acetamide }\end{array}$ & & 480 & No dissociation " & 1.88 & 226.1 & 14.5 \\
\hline Pethoxamid & $\begin{array}{l}\text { 2-chloro-N-(2-ethoxyethyl)-N-(2- } \\
\text { methyl-1-phenylprop-1-envl) } \\
\text { acetamide }\end{array}$ & & 400 & No dissociation ${ }^{2}$ & 4.4 & 211 & 6.3 \\
\hline Dimethenamid-p & $\begin{array}{l}\text { (S)-2-chloro-N-(2,4-dimethyl-3- } \\
\text { thienyl)-N-(2-methoxy-1- } \\
\text { methylethyl) acetamide }\end{array}$ & & 1499 & No dissociation " & 3.69 & 227 & 23 \\
\hline
\end{tabular}

Sorption experiment

The batch equilibrium method was used to conduct the sorption experiment (OECD 2000). Stock solutions were prepared using $0.01 \mathrm{M} \mathrm{CaCl}_{2}$ aqueous solution containing $1,2.5,5,10$ and $25 \mu \mathrm{g} \mathrm{mL}^{-1}$ of each herbicide. 10 grams of air-dried, ground, and sieved $(\leq 2 \mathrm{~mm})$ soil samples were put in $50 \mathrm{~mL}$ of glass 
bottles in triplicates and $20 \mathrm{~mL}$ of stock solutions were added. The bottles were then placed on a mechanical shaker for 24 hours at room temperature $\left(20^{\circ} \mathrm{C}\right)$ and centrifuged at (13,000 rpm) for 10 minutes. Supernatants were filtered by a glass syringe filter $(0.7 \mu \mathrm{m})$ and then analyzed by HPLC-UV (Dionex, USA). The amount of herbicide adsorbed to soil particle $\left(\mu \mathrm{g} \mathrm{g}^{-1}\right)$ was calculated from the difference between the initial and final concentrations $\left(\mu \mathrm{g} \mathrm{cm}{ }^{-3}\right)$ of the solution. The sorption isotherms were described using the Freundlich equation as follows:

$$
C_{s}=\mathrm{K}_{\mathrm{f}} \mathrm{C}_{e}^{1 / n}
$$

where $C_{s}$ is the amount of herbicide adsorbed to the soil $\left(\mu \mathrm{g} \mathrm{g}^{-1}\right), C_{e}$ is the equilibrium concentration in solution $\left(\mu \mathrm{g} \mathrm{cm}^{-3}\right), K_{f}$ and $1 / \mathrm{n}$ are empirical constants. The distribution coefficient $\left(K_{d}\right)$ for all soils were calculated (see Supporting information S2)

Degradation experiment

The degradation experiment was carried out using a standard procedure (OECD 2002). The soil samples were dried in the laboratory, plant parts, and the seeds were removed before grinding and the soil was passed through a $2 \mathrm{~mm}$ sieve. Fifty grams of soil were placed in $50 \mathrm{~cm}^{3} \mathrm{glass}$ bottles and the herbicide solution was added separately. The preparation time for soil samples did not exceed five days. The herbicide solubility in the initial solution was increased by methanol and a stock solution of $0.01 \mathrm{M} \mathrm{CaCl}_{2}$ was prepared. Based on the soil water retention capacity (Kodešová et al. 2009), samples received different amounts of solution in three replicates: Volárna $(8 \mathrm{~mL})$, Suchdol and Dobroměrice $(12.5 \mathrm{~mL})$. The range of concentrations used for each compound in the degradation experiment was chosen based on the recommended dose of each compound. The following initial concentrations were assumed: $20.52 \mathrm{mg}^{-1}$ aclonifen for Volárna $(V), 21.22 \mathrm{mg} \mathrm{g}^{-1}$ for Suchdol and Dobroměrice $(S+D), 11.20$ and $10.94 \mathrm{mg} \mathrm{g}^{-1}$ of dimethenamid-p for $(V)$ and $(S+D), 6.73$ and 7.43 $\mathrm{mg} \mathrm{g}^{-1}$ of flurochloridone for $(\mathrm{V})$ and $(\mathrm{S}+\mathrm{D}), 14.61$ and $14.67 \mathrm{mg} \mathrm{g}^{-1}$ of pendimethalin for $(\mathrm{V})$ and $(\mathrm{S}+\mathrm{D}), 13.10$ and $12.84 \mathrm{mg} \mathrm{g}^{-1}$ of s-metolachlor for $(\mathrm{V})$ and $(S+D), 12.43$ and $12.57 \mathrm{mg} \mathrm{g}^{-1}$ of pethoxamid for $(\mathrm{V})$ and $(\mathrm{S}+\mathrm{D})$. The treated samples were mixed and incubated in a thermostat at $20^{\circ} \mathrm{C}$ constant temperature. During the incubation period, the moisture content of the samples was monitored once a week and the caps were not tightly closed to prevent anaerobic conditions. The incubation period was $0,1,2,5,12,23,46,80$ and 120 days. Samples were collected at predetermined intervals and immediately stored in a freezer at $-20^{\circ} \mathrm{C}$ until further processing of the extractions. The soils were dispersed in $50 \mathrm{~mL}$ of methanol and the bottles were shaken for 24 hours (at $200 \mathrm{rpm}$ ). The extracts were centrifuged for 10 minutes (at $4700 \mathrm{rpm}$ ) and then filtered using a $0.7 \mu \mathrm{m}$ glass syringe filter and transferred to $1.5 \mathrm{ml}$ vials. The modified method by Kočárek et al. (2016) was used to determine the residual concentration of herbicides in soil solution ( $\mu \mathrm{g} \mathrm{cm}^{-3}$ ) using the $\mathrm{HPLC}$ (Dionex; USA) technique. The rate of degradation and half-life $\left(\mathrm{DT}_{50}\right)$ of herbicides were calculated using the following equation:

$$
\frac{C_{t}}{c_{0}}=e^{-k_{R} t} \quad[2]
$$

where $C_{t}$ is the residual amount of herbicide in soil $\left(\mu \mathrm{g} \mathrm{g}^{-1}\right), C_{0}$ is the initial concentration of herbicide in solution $\left(\mu g^{-1}\right), t$ is time $\left(\right.$ days), and $k_{R}$ is degradation rate constant $\left(\right.$ day $\left.^{-1}\right)$. The half-life $\left(\mathrm{DT}_{50}\right)$ of herbicides (day) was calculated as follows:

$\mathrm{DT}_{50}=\frac{\ln 2}{\mathrm{k}_{\mathrm{R}}}$

Statistical analyses

Statistical analysis was carried out to determine the relationship between treatment variables. A simple and multiple correlation analysis between soil properties and absorption coefficient and degradation experiment results were evaluated using the Pearson correlation coefficient and p-value. The soil properties (Table 1) were the main predictor of correlation analysis and the statistically significant level was always 0.05 or lower. All analysis was performed using the Statistica ${ }^{\circledR} 13$ (StatSoft, Inc. Oklahoma, USA).

\section{Results}

Sorption isotherm of herbicedes

The herbicides Freundlich sorption isotherms are presented in Fig. 1, and sorption parameters $\left(K_{f}\right.$ and $\left.n\right)$ together with the regression coefficients and $R^{2}$ values calculated for herbicides with three soils are given in Table 3 . The $K_{f}$ values ranged from 1.07 to $135.37 \mathrm{~cm}^{3 / n} \mu g^{1-1 / n} \mathrm{~g}^{-1}$ and sorption of herbicides increased in the order dimethenamid-p < pethoxamid < s-metolachlor < flurochloridone < aclonifen < pendimethalin. The slopes $(n>1)$ of isotherm of herbicides calculated for three soils indicated a high level of linearity as $n$ values, being higher than 1 , excluding flurochloridone (Table 3 ). Among the six herbicides, the highest $\mathrm{K}_{\mathrm{f}}$ value reported was systematically observed in Haplic Fluvisol (a loam with high $\mathrm{OM}$ and lower $\mathrm{pH}$, Table 1 ). The $\mathrm{K}_{\mathrm{f}}$ values in this soil ranged from 2.41 to $135.37 \mathrm{~cm}^{3 / \mathrm{n}} \mu \mathrm{g}^{1-1 / n} \mathrm{~g}^{-1}$ for dimethenamid-p and pendimethalin. The lowest sorption values were found in the Arenic Regozem (a sandy loam with low $\mathrm{OM}$ and higher $\mathrm{pH}$ ) for dimethenamid-p and pethoxamid. It should be noted that pendimethalin displayed the highest $\mathrm{K}_{\mathrm{f}}$ values and was more strongly adsorbed on all three soils than any of the other herbicides (Table 3 ). 
The Freundlich adsorption coefficients, $\mathrm{K}_{\mathrm{f}}\left(\mathrm{cm}^{3 / \mathrm{n}} \mu \mathrm{g}^{1-1 / n} \mathrm{~g}^{-1}\right)$ for the studied herbicides and $\mathrm{n}$ values for three soils.

\begin{tabular}{|c|c|c|c|c|c|c|c|c|c|c|c|c|c|c|c|c|c|}
\hline \multirow{2}{*}{$\begin{array}{l}\text { Location/Soil } \\
\text { type }\end{array}$} & \multicolumn{3}{|c|}{ Dimethenamid-p } & \multicolumn{3}{|c|}{ Pethoxamid } & \multicolumn{3}{|c|}{ S-Metolachlor } & \multicolumn{3}{|c|}{ Flurochloridone } & \multicolumn{3}{|c|}{ Aclonifen } & \multicolumn{2}{|c|}{ Pendimethali } \\
\hline & $K_{f}$ & $\mathrm{n}$ & $\mathrm{R}^{2}$ & $K_{f}$ & $\mathbf{n}$ & $\mathbf{R}^{2}$ & $K_{f}$ & $\mathrm{n}$ & $\mathrm{R}^{2}$ & $K_{f}$ & $\mathrm{n}$ & $\mathrm{R}^{2}$ & $K_{f}$ & $\mathrm{n}$ & $\mathrm{R}^{2}$ & $K_{f}$ & $\mathbf{n}$ \\
\hline $\begin{array}{l}\text { Suchdol - } \\
\text { Haplic } \\
\text { Chernozem }\end{array}$ & 1.57 & 1.20 & 0.998 & 3.07 & 1.21 & 0.998 & 3.30 & 1.23 & 0.998 & 15.83 & 0.80 & 0.996 & 42.56 & 1.53 & 0.991 & 82.31 & 1.5 \\
\hline $\begin{array}{l}\text { Dobroměřice } \\
\text { - Haplic } \\
\text { Fluvisol }\end{array}$ & 2.41 & 1.17 & 0.999 & 5.61 & 1.12 & 0.999 & 5.32 & 1.18 & 0.998 & 27.32 & 0.85 & 0.997 & 81.42 & 1.43 & 0.972 & 135.37 & 1.3 \\
\hline $\begin{array}{l}\text { Volárna - } \\
\text { Arenic } \\
\text { Regozem }\end{array}$ & 1.07 & 1.15 & 0.999 & 1.88 & 1.09 & 0.999 & 2.31 & 1.13 & 0.999 & 12.77 & 0.76 & 0.993 & 27.02 & 1.68 & 0.983 & 73.33 & 1.5 \\
\hline $\begin{array}{l}\text { Average } \mathrm{K}_{\mathrm{F}} \\
\text { value }\end{array}$ & 1.68 & & & 3.52 & & & 3.65 & & & 18.64 & & & 50.33 & & & 97.00 & \\
\hline $\begin{array}{l}\text { Standard } \\
\text { deviation }\end{array}$ & 0.7 & & & 1.9 & & & 1.5 & & & 7.7 & & & 28.0 & & & 33.5 & \\
\hline Range & 1.33 & & & 3.73 & & & 3.01 & & & 14.55 & & & 54.39 & & & 62.04 & \\
\hline
\end{tabular}

Herbicides degradation

Degradation rate and half-lives ( $\mathrm{DT}_{50}$ ) values for herbicides are shown in Table 7. Degradation curves for six herbicides in three soils are presented in Supporting information Fig. S1. The degradation rate decreased in the order aclonifen $<$ pethoxamid $<$ dimethenamid-p $<$ pendimethalin $<$ flurochloridone $<$ smetolachlor. Degradation rate constants of herbicides were in the range of $0.012-0.048 \mathrm{~d}^{-1}$ which, corresponds to half-lives between 14-57 days. The longest $\mathrm{DT}_{50}$ values for herbicides were observed in Haplic Fluvisol, while the shortest values were in Haplic Chernozem (Table 7). The findings of herbicide degradation were statistically analyzed and the rate of degradation with clay content was positively correlated and a negative correlation was found with the $\mathrm{OM}$ and CEC contents. The rate of degradation was positively correlated with soil $\mathrm{pH}(\mathrm{r} \geq 0.725, \mathrm{p}<0.01)$, positive but not significantly correlated with clay content, and negatively correlated with OM $(r \geq-0.942, p<0.001)$, and CEC $(r \geq-0.940, p<0.001)$ for all three soils (Table 8).

Table 7

The dissipation half-lives, $\mathrm{DT}_{50}$ (day), and kinetic rate constants, $\mathrm{k}_{\mathrm{R}}\left(\right.$ day $\left.^{-1}\right)$, of herbicides in soil.

\begin{tabular}{|c|c|c|c|c|c|c|c|c|c|c|c|c|}
\hline \multirow[t]{2}{*}{ Soil } & \multicolumn{2}{|c|}{ Pendimethalin } & \multicolumn{2}{|c|}{ Aclonifen } & \multicolumn{2}{|c|}{ Flurochloridone } & \multicolumn{2}{|c|}{ S-Metolachlor } & \multicolumn{2}{|c|}{ Pethoxamid } & \multicolumn{2}{|c|}{ Dimethenamide-p } \\
\hline & $k_{R}$ & $\mathrm{DT}_{50}$ & $k_{R}$ & $\mathrm{DT}_{50}$ & $k_{R}$ & $\mathrm{DT}_{50}$ & $k_{R}$ & $\mathrm{DT}_{50}$ & $k_{R}$ & $\mathrm{DT}_{50}$ & $k_{R}$ & $\mathrm{DT}_{50}$ \\
\hline Suchdol & 0.040 & 17 & 0.048 & 14 & 0.018 & 38 & 0.019 & 37 & 0.040 & 17 & 0.037 & 19 \\
\hline Dobroměřice & 0.014 & 51 & 0.035 & 20 & 0.015 & 46 & 0.012 & 57 & 0.027 & 26 & 0.020 & 34 \\
\hline Volarna & 0.030 & 23 & 0.037 & 19 & 0.014 & 51 & 0.015 & 47 & 0.040 & 17 & 0.032 & 21 \\
\hline Standard deviation & 0.013 & 18.1 & 0.007 & 3.2 & 0.002 & 6.6 & 0.003 & 10.0 & 0.008 & 5.2 & 0.009 & 8.1 \\
\hline Average $\mathrm{k}_{\mathrm{R}}$ and $\mathrm{DT}_{50}$ & 0.028 & 30 & 0.040 & 18 & 0.016 & 45 & 0.015 & 47 & 0.036 & 20 & 0.030 & 25 \\
\hline
\end{tabular}

Table 8

Statistical correlations between degradation rate $k_{R}$ and selected soil properties plus $\mathrm{K}_{\mathrm{f}}$.

\begin{tabular}{|c|c|c|c|c|c|c|}
\hline & $K_{f}$ & $\mathrm{pH}_{\mathrm{H} 2 \mathrm{O}}$ & OM & $\mathrm{CaCO}_{3}$ & CEC & Clay \\
\hline Pendimethalin & $-0.865^{\star *}$ & 0.405 & $-0.741^{\star \star}$ & -0.003 & $-0.737^{\star \star}$ & $0.536^{*}$ \\
\hline Aclonifen & -0.377 & 0.092 & -0.319 & -0.491 & -0.314 & $0.880^{\star \star \star}$ \\
\hline Flurochloridone & -0.082 & -0.461 & 0.061 & $-0.783^{* *}$ & 0.067 & $0.994^{* * x}$ \\
\hline S-metolachlor & $-0.595^{*}$ & 0.204 & $-0.583^{*}$ & -0.214 & $-0.579^{*}$ & $0.702^{\star \star}$ \\
\hline Pethoxamid & $-0.950^{\star * \star}$ & $0.725^{\star \star}$ & $-0.942^{\star \star \star}$ & 0.381 & $-0.940^{\star * \star}$ & 0.171 \\
\hline Dimethenamid-p & $-0.788^{\star \star}$ & 0.498 & $-0.807^{\star \star \star}$ & 0.100 & $-0.803^{\star \star \star}$ & 0.446 \\
\hline
\end{tabular}




\section{Discussion}

Sorption behavior of herbicides

In terms of $\mathrm{K}_{\mathrm{f}}$ parameters, our findings are in agreement with those shown by Wauchope et al. (1992) and Rytwo et al. (2005), which addressed the strong affinity of pendimethalin to solid phases due to its hydrophobic nature. Kočárek et al. (2018) previously studied sorption isotherms of pendimethalin under laboratory conditions and obtained a higher $K_{f}$ value $\left(270.1 \mathrm{~cm}^{3 / n} \mu g^{1-1 / n} \mathrm{~g}^{-1}\right)$ in a silt loam soil. Aclonifen showed significantly lower $K_{f}$ values than that shown in PPDB $\left(K_{f}=138.1 \mathrm{~cm}^{3 / n} \mu g^{1-1 / n} g^{-1}\right)$. On the other hand, Trevisan et al. (1999) tested the sorption of aclonifen in 9 different soil types corresponding to our soil characteristics and determined significantly higher $\mathrm{K}_{\mathrm{d}}$ values between 8.54 -and $602.60 \mathrm{~mL} \mathrm{~g}^{-1}$. As mentioned above, the Freundlich isotherm for flurochloridone adsorption is defined as an S-type curve, since $n$ values were $<1$ in the three soils and ranged from 0.76 to 0.85 , respectively. This indication shows that flurochloridone has a relatively higher affinity for all three soils at a low concentration and that adsorption can decrease at a high concentration (Pinna et al. 2014). Sorption coefficient $\left(K_{f}\right)$ values (Table 3) for s-metolachlor, pethoxamid, and dimethenamid-p show that they have a considerably lower sorption behavior compared to the other three herbicides. This was probably due to their physicochemical properties such as a smaller polar surface area (Å2) and high-water solubility (Table 2). However, the $K_{d}$ values for $s$-metolachlor were within the range of previously reported findings for soils with similar properties, e.g. $0.51-3.40 \mathrm{~cm}^{3} \mathrm{~g}^{-1}$ (Si et al. 2009), 0.76-16.67 $\mathrm{cm}^{3} \mathrm{~g}^{-1}$ (Westra et al. 2015), and 0.6-5.7 $\mathrm{cm}^{3} \mathrm{~g}^{-1}$. (Weber et al. 2003). The $\mathrm{K}_{\mathrm{f}}$ values of pethoxamid for three soils are within the range of $1.88-5.61 \mathrm{~cm}^{3 / \mathrm{n}} \mu \mathrm{g}^{1-1 / \mathrm{n}} \mathrm{g}^{-1}$, while its highest sorption was indicated in Haplic Fluvisol. Pose-Juan et al. (2018) recently investigated the sorption of pethoxamid in amended and unamended sandy loam soil, resulting in significantly low $\mathrm{K}_{\mathrm{f}}$ values $0.20 \mathrm{~cm}^{3 / \mathrm{n}} \mu \mathrm{g}^{1-}$

${ }^{1 / n} \mathrm{~g}^{-1}$ for the unamended soil. Furthermore, a high level of linearity was observed in the unamended soil by the pethoxamid adsorption curve ( $\left.n_{f}=1,68\right)$, whereas its sorption by amended soil was near to the linearity of (C-type) (Pose-Juan et al., 2018). Dimethenamid-p showed the lowest $K_{f}$ values in the studied soils and was relatively smaller than the value in PPDB (2019), $\left(K_{f}=3.69 \mathrm{~cm}^{3 / n} \mu g^{1-1 / n} g^{-1}\right)$. Kočárek et al. (2018) also reported a small sorption value $\left(K_{f}=\right.$ $2.12 \mathrm{~cm}^{3 / n} \mu \mathrm{g}^{1-1 / n} \mathrm{~g}^{-1}$ ) for dimethenamid-p in silt loam soil. Westra et al. (2015) examined dimethenamid-p sorption in 25 different soils and the mean $K_{d}$ values calculated for soils were $2.3 \mathrm{~cm}^{3} \mathrm{~g}^{-1}$.

The effect of soil properties on herbicide sorption.

Table 4 shows the statistical correlation between herbicide's $K_{f}$ coefficients and soil properties. Consistent with the herbicide's properties and pKa values (Table 2), their molecules are in neutral form and behave as a non-ionic organic compound. Recently published authors have stated that hydrogen bonding is a key mechanism for the sorption of non-ionic molecules on soil OM and clay minerals. The effect of OM on the sorption of non-ionic herbicides was evaluated under different soil conditions. For the compounds flurochloridone, s-metolachlor, dimethenamid-p, and pethoxamid, our findings support the predicted interactions described in the literature (Weber et al. 2000; Weber et al. 2004; Pinna et al. 2014; Pose-Juan et al. 2018). The $K_{f}$ coefficient of herbicides was strongly correlated with OM and CEC (at $p<0.001$ ), (Table 4). This indicates that they are the major predictors of sorption and increase affinity to soils with a high OM content. Besides, a positive correlation was observed between OM and CEC $(r \geq 0.989, p<0$. 001), and no relationship was found between clay content and CEC (Table 5).

Table 4

Statistical correlations between the $\mathrm{K}_{\mathrm{f}}$ coefficients and soil properties: $\mathrm{pH}_{\mathrm{KCl}}, \mathrm{pH}_{\mathrm{H} 2 \mathrm{O}}$, organic matter content $(\mathrm{OM}), \mathrm{CaCO}_{3}$ content, cation exchange capacity (CEC), sand, silt and clay content.

\begin{tabular}{|c|c|c|c|c|c|c|c|c|}
\hline & $\mathrm{pH}_{\mathrm{KCl}}$ & $\mathrm{pH}_{\mathrm{H} 2 \mathrm{O}}$ & OM & $\mathrm{CaCO}_{3}$ & CEC & Sand & Silt & Clay \\
\hline Pendimethalin & -0.147 & $-0.829 * \star \star$ & 0.981 *** & $-0.513^{\star}$ & $0.974 * \star \star$ & -0.095 & 0.108 & -0.013 \\
\hline Aclonifen & -0.286 & $-0.899 \star \star \star$ & $0.996 * \star \star$ & $-0.633^{\star}$ & $0.995^{\star \star \star}$ & -0.240 & 0.252 & 0.133 \\
\hline Flurochloridone & -0.210 & $-0.863^{\star \star \star}$ & 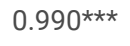 & $-0.569 *$ & $0.986^{\star * *}$ & -0.161 & 0.173 & 0.053 \\
\hline S-metolachlor & -0.332 & $-0.919 * \star \star$ & $0.996 * \star \star$ & $-0.669 *$ & $0.996 * \star \star$ & -0.286 & 0.297 & 0.180 \\
\hline Pethoxamid & -0.320 & $-0.914 * \star \star$ & $0.995^{\star \star \star}$ & $-0.661^{*}$ & 0.996 *** & -0.275 & 0.287 & 0.169 \\
\hline Dimethenamid-p & -0.378 & $-0.933^{\star \star *}$ & $0.992^{\star \star \star}$ & $-0.705^{\star \star}$ & $0.997 * \star \star$ & -0.333 & 0.344 & 0.228 \\
\hline
\end{tabular}


Table 5

The correlation coefficients describing relationship between soil properties: $\mathrm{pH}_{\mathrm{KCl}}, \mathrm{pH}_{\mathrm{H} 2 \mathrm{O}}$, organic matter content (OM \%), $\mathrm{CaCO}^{3}$ content (\%), cation exchange capacity (CEC mmol $\mathrm{kg}^{-1}$ ), sand,

\begin{tabular}{|c|c|c|c|c|c|c|c|c|}
\hline & $\mathrm{pH}_{\mathrm{KCl}}$ & $\mathrm{pH}_{\mathrm{H} 2 \mathrm{O}}$ & OM & $\mathrm{CaCO}_{3}$ & CEC & Sand & Silt & Clay \\
\hline $\mathrm{pH}_{\mathrm{KCl}}$ & 1 & & & & & & & \\
\hline $\mathrm{pH}_{\mathrm{H} 2 \mathrm{O}}$ & $0.660^{*}$ & 1 & & & & & & \\
\hline $\mathrm{OM}$ & -0.305 & $-0.905^{\star \star \star}$ & 1 & & & & & \\
\hline $\mathrm{CaCO}_{3}$ & $0.907^{\star \star \star}$ & $0.895^{* *}$ & $-0.647^{*}$ & 1 & & & & \\
\hline CEC & -0.346 & $-0.919^{\star \star \star}$ & $0.989^{\star \star \star}$ & $-0.680^{\star}$ & 1 & & & \\
\hline Sand & $0.976^{\star \star \star}$ & $0.622^{*}$ & -0.262 & $0.903^{\star \star \star}$ & -0.301 & 1 & & \\
\hline Silt & $-0.976^{\star \star \star}$ & $-0.631^{*}$ & 0.274 & $-0.908^{\star \star \star}$ & 0.313 & $-1.000^{\star \star \star}$ & 1 & \\
\hline Clay & $-0.964^{\star \star \star}$ & $-0.535^{\star}$ & 0.155 & $-0.851^{\star *}$ & 0.196 & $-0.994^{\star \star \star}$ & $0.992^{\star \star *}$ & 1 \\
\hline
\end{tabular}

In general, organic matter has a high sorption capacity, in particular compounds with lower water solubility (Carringer et al. 1975), even though the structure of the pendimethalin and aclonifen molecules have considerably low water solubility $\left(0.33\right.$ and $\left.1.4 \mathrm{mg} \mathrm{L}^{-1}\right)$ and high $\mathrm{K}_{\text {foc }}$ values $\left(13,792\right.$ and $7,126 \mathrm{~cm} / \mathrm{n} \mu \mathrm{g}^{1-}$ $1 / n \mathrm{~g}^{-1}$ ) (Table 2). However the findings suggested that the adsorption of all six herbicides was positively related to $0 \mathrm{M}(\mathrm{r} \geq 0.981, \mathrm{p}<0.001)$ regardless of their water solubility and $\mathrm{K}_{\mathrm{foc}}$ values. It should be noted that some of the hydrophobic pesticide mobility can be increased in soils with a high OM content due to increased solubility of compounds in the presence of dissolved organic carbon (DOC) as shown by Kodešová et al. (2012) for chlorotoluron and in the case of DDT. Soil minerals and organic components are used to determine the soil sorption potential of pesticides, particularly non-ionic compounds such as atrazine (Spark and Swift 2002; Ben Hur et al. 2003). Ben Hur et al. (2003) the contribution of clay minerals to pesticides can be significant, when the ratio between clay minerals and a fraction of organic carbon is greater than 30. A small ratio was observed between soils, except for Haplic Fluvisol (the ratio clays/OC was 35). However, the effect of clay content on herbicide sorption was not observed for all tested soils, as $\mathrm{K}_{\mathrm{f}}$ values and clay content was not significantly correlated $(r \leq 0.228)$ (Table 4$)$. On the other hand, it is difficult to assess the influence of a single soil property on soil sorption, since they are always correlated. Table 5 shows the relationship between soil properties where soil $\mathrm{pHH}_{2} \mathrm{O}$ was negatively correlated with $\mathrm{OM}(\mathrm{r} \geq-0.905, \mathrm{p}<0$. 001$)$, and $\operatorname{CEC}(r \geq-0.919, p<0.001)$.

The $\mathrm{K}_{\mathrm{f}}$ was negatively correlated to soil $\mathrm{pHH}_{2} \mathrm{O}(r \geq-0.829, \mathrm{p}<0.001)$. A negative but not significant correlation was also observed between $\mathrm{K}_{\mathrm{f}}$ and $\mathrm{pHKCL}$ for all herbicides (Table 4). Weber et al. (1989) indicated that pesticide adsorption by hydrophobic bonding is pH-independent. Ahmad et al. (2014) reported that the sorption behavior of the molecule is influenced by the $\mathrm{pKa}$ of the herbicide and the $\mathrm{pH}$ of the soil solution. As the sorption of non-ionic molecules is less affected by soil pH (Kan and Tomson 1990). In our study, the pKa values of pendimethalin and aclonifen appeared to be insignificant for soil sorption. Based on the information provided in PPDB (2019), both pendimethalin and aclonifen are acidic herbicides and the dissociation of pendimethalin is somewhat inconsistent (Kočárek et al. 2018), but stable in the pH range 4-9 (Sakaliene et al. 2007). Aclonifen, which has a pKa of -3.15 (PPDB, 2019 ), was neutral in the current experiment, as the $\mathrm{pH}$ of soil solutions ranged from 7.8 to 8.2 (Table 1). This means that those two herbicides cannot be completely dissolved. In this case, sorption processes could not have occurred through anionic-cation pathways, but through hydrogen bonds, Van der Waals force, or hydrophobic partitioning (Trevisan et al. 1999; Shetti et al. 2019). There was a negative correlation between the $\mathrm{K}_{\mathrm{f}}$ coefficient and the CaCO $\mathrm{C}_{3}$ content $(r$ $\geq-0.513, p<0.05)$ for all herbicides. Sorption of 2,4-D was studied by Rodriguez-Rubio et al. (2006), and found that soil with a very large amount of $\mathrm{CO}_{3}{ }^{2-}$ content was necessary for sorption. In our case, however, the opposite effect has occurred, and it is predicted that the adsorption of herbicides would not be favored by $\mathrm{CaCO}_{3}$. Also, Kodešová et al. (2011) suggest that the $\mathrm{CaCO}_{3}$ is not sufficient for the evaluation of herbicide sorption, as the resulting correlation may be based on extremely high or very low $\mathrm{CaCO}_{3}$ values. As stated above, the clay and silt content were not correlated with the sorption coefficient and a slightly negative but not significant correlation was observed with sand content (Table 4). This indicates that they were not the main predictors of the sorption of the studied herbicides, and support the findings of (Weber et al. 2004; Alletto et al. 2013; Westra et al. 2015), while the findings of Peter and Weber (1985) suggest that the clay content has a direct influence on the sorption of alachlor and metolachlor. The correlations between $\mathrm{K}_{\mathrm{f}}$ values in all six herbicides are summarized in Table 6. A strong positive correlation was observed between the sorption coefficient of the herbicide. As already discussed, this may be due to the sorption mechanism of these herbicides, which prevails as non-ionizable compounds and are mainly present in their neutral form. In addition, similar behavior of herbicides can be predicted under the same soil conditions. 
Table 6

Correlation matrix between the $\mathrm{K}_{\mathrm{f}}$ coefficients of different herbicides.

\begin{tabular}{|c|c|c|c|c|c|c|}
\hline & Pendimethalin & Aclonifen & Flurochloridone & S-metolachlor & Pethoxamid & Dimethenamid-p \\
\hline Pendimethalin & 1 & & & & & \\
\hline Aclonifen & $0.998^{\star \star \star}$ & 1 & & & & \\
\hline Flurochloridone & $0.999^{\star \star \star}$ & $1.000^{\star \star \star}$ & 1 & & & \\
\hline S-metolachlor & $0.985^{\star \star \star}$ & $0.993^{\star \star \star}$ & $0.992^{\star \star \star}$ & 1 & & \\
\hline Pethoxamid & $0.996^{\star \star *}$ & $0.999^{\star \star \star}$ & $0.999^{\star \star \star}$ & $0.997^{\star \star \star}$ & 1 & \\
\hline Dimethenamid-p & $0.972^{\star \star \star}$ & $0.983^{\star \star \star}$ & $0.981^{\star \star \star}$ & $0.998^{\star \star \star}$ & $0.989^{\star \star \star}$ & 1 \\
\hline
\end{tabular}

The effects of soil properties on herbicide degradation

Several authors have proposed that sorbed chemicals are less available for transport and degradation (Selim et al. 1999; Koskinen et al. 2001). It can be assumed that the longest $\mathrm{DT}_{50}$ values were possibly due to the higher OM content in the soil (Table 1). The high $\mathrm{DT}_{50}$ values could also be explained by the sorption coefficient $\left(\mathrm{K}_{\mathrm{f}}\right)$ of herbicide. The $\mathrm{DT}_{50}$ values may also be increased if microbiological degradation is the key dissipation mechanism (Felsot and Dzantor 1995; Munoz-Leoz et al. 2013).

The degradation rate of two herbicides significantly correlated only with soil $\mathrm{pH}$; a positive correlation for pethoxamid, and a negative but not significant correlation for flurochloridone. For other herbicides, weak positive correlations were observed between soil pH and degradation rate. Aclonifen and pethoxamid showed faster degradation and shorter dissipation half-lives in the studied soils. The average values were 18 days for aclonifen and 20 days for pethoxamid. Shortest values were found in Haplic Chernozem and Arenic Regozem (Table 7). The obtained half-life for aclonifen was much shorter than the value presented (62.3 days) in PPDB (2019), and for pethoxamid, it is significantly higher than those stated in the literature (Pose-Juan et al. 2018; Rodriguez-Cruz et al. 2019). Vischetti et al. (2002) also observed a high aclonifen half-life (40.3 to 49.1 days) in the laboratory under different temperature and soil moisture conditions in sandy clay loam soil. As shown in Table 8, the rate of degradation of aclonifen was positively correlated with clay content ( $r \geq 0$. 880, $p<0.001$ ), positive but not significantly correlated with soil $\mathrm{pH}$, and a negative but not significant correlation was observed with $\mathrm{OM}, \mathrm{CaCO}$, and $\mathrm{CEC}$ for all three soils. Based on data from the Pesticide Properties DataBase (PPDB), aclonifen is stable between pH 5 to 9 at $22-70^{\circ} \mathrm{C}$ and photolysis is not a major route of degradation (PPDB 2019). It is known that microbiological degradation takes more time and the results suggest that degradation of aclonifen was mainly caused by chemical hydrolysis and/or oxidation due to its shortest half-life among the herbicides.

The faster degradation rate and shorter $\mathrm{DT}_{50}$ values obtained for pethoxamid could be explained by its low adsorption capacity (Table 3 ), which were more available in dissolved organic carbon (DOC). According to Marín-Benito et al. (2012) dissolved organic carbon can adsorb herbicide and may increase the bioavailability for degradation. Pethoxamid dissipation in soil was studied by Dhareesank et al. (2005), and stated that rapid dissipation could be explained by its irreversible adsorption and hydrophobic character. Rodriguez-Cruz et al. (2019) investigated the dissipation of pethoxamid at different initial concentrations, and the results indicated that organic residues would decrease the dissipation rate at the lowest dosage rate $\left(2 \mathrm{mg} \mathrm{kg}^{-1}\right)$.

The dissipation half-lives for dimethenamid-p in the three soils ranged from 19 to 34 days, which were almost within the range of DT 50 (7.7-31.5 days) reported in EFSA (2018). A longer dissipation half-life value of 34 days was found in Haplic Fluvisol, and significantly lower values were observed in Haplic Chernozem and Arenic Regozem (Table 7). The degradation rate was negatively correlated with OM $(r \geq-0.807, p<0.001)$, and CEC ( $\geq-0$. 803, $p<0.001)$, positive but not significantly correlated with clay content, as well as soil pH and CaCO3 for all three soils (Table 8). Based on the EFSA (2018) data, dimethenamid-p is characterized as stable in hydrolysis, while photolysis in water and soil takes place relatively quick (3-5 weeks). In this study, an increase of dissipation half-life of herbicides was observed mainly in soils with higher OM content, and this has also been observed for dimethenamid-p in similar conditions, even though dimethenamid-p has higher water solubility and lower $\mathrm{K}_{\text {foc }}$ values (Table 2) in comparison with other herbicides. It should also be noted that our findings are compatible with the previous study, which indicates that dimethenamid-p appears to be bound immediately to soil particles or dissolved in soil solution and then desorbed into the soil solution, where readily degraded by soil microorganisms (Kočárek et al. 2018). The pendimethalin's half-life reported here was shorter than the value of 182.3 days as presented in PPDB (2019). The calculated half-life values were extremely short, especially in Haplic Chernozem (more than 10 times) and Arenic Regozem (around 8 times) (Table 7). Despite this, the average pendimethalin half-life value was within the same range (24.4-34.4 days) as those calculated by Kočárek et al. (2016) in a Haplic Chernozem soil under greenhouse conditions. These findings indicate that pendimethalin was rapidly degraded in the studied soils; thus, the rate of dissipation was not related to the hydrophobicity and the degree of adsorption, even though the pendimethalin was strongly adsorbed by all three soils (Table 3 ). There was a positive correlation between degradation rate and clay content $(r \geq 0.536, p<0.05)$ and, a negative correlation with $O M(r \geq-0.741, p<0.01)$ and CEC $(r \geq-0.737, p<0.01)$ and, a negative but not significant correlation with $\mathrm{CaCO}_{3}$ (Table 8). The dissipation half-lives (from 38 to 51 days) for flurochloridone in three soils were consistent with those previously reported, ranging from 9 to 66 days (EFSA, 2010). A longer dissipation half-life (51 days) was found in Arenic Regozem (Table 7). Available data on flurochloridone soil persistence under laboratory conditions is scarce. Walker. (1987) obtained a similar DT 50 value (40 and 90 days) for flurochloridone incubated in the laboratory at 20 and $10^{\circ} \mathrm{C}$ in sandy loam soil. According to information presented in PPDB (2019), flurochloridone is moderately persistent and its main degradation pathway is by chemical hydrolysis. The degradation rate of flurochloridone positively correlated with clay content ( $r \geq 0$. 994, $p<0$. 001), and negatively with $\mathrm{CaCO}_{3}(r \geq-0.783, \mathrm{p}<0.05)$, and a positive but not significant correlation was observed with OM and CEC. A slightly negative correlation was 
found with soil pH for all three soils (Table 8). The clay content seems to be the predominant factor in the determination of the dissipation of flurochloridone due to its strong correlation with the rate of degradation. Indeed, there was not a significant relationship between the OM content and the rate of degradation. In addition, it could also be hypothesized that the degradation of flurochloridone may decrease (longer half-life) in soils with higher $\mathrm{pH}$. The observed half-life values for s-metolachlor ranged from 37 to 57 days, and the highest value was found in Haplic Fluvisol (Table 7). The degradation of s-metolachlor has previously been evaluated in several studies. Our results were comparable to those reported by Rice et al. (2002) for a half-life of 9. 6-81 days and slightly higher than those reported by Wu et al. (2011) (37.9-49.5) days in five different soils. Assuming that s- metolachlor is more persistent in high OM soil than in low OM soil. Therefore, a negative correlation between the degradation rate and OM content $(r \geq-0.583, p<0.05)$ and CEC $(r \geq-0.579, p<0.05)$ were observed, while a significant positive correlation was found with clay content $(r \geq 0.702, p<0.01)$ for all soils (Table 8). Consequently, a decrease in soil OM content and an increase in clay content result in a reduction in the half-life of $s$-metolachlor in soils.

In summary, it seems likely that the degradation of herbicides in soils was affected by several parameters, including OM content, clay content, CEC, and soil $\mathrm{pH}$. However, in most cases, OM content showed a statistically significant relationship between the herbicides adsorption coefficient and the rate of degradation. This suggests that they may be inversely related. Correlation analysis shows that soil pH was negatively correlated with herbicide sorption (Table 4), and according to Villaverde et al. (2008) it is often estimated that degradation is supported by a higher amount of chemical present in the solution. Finally, as predicted, there was a negative association between the adsorption coefficient $\left(\mathrm{K}_{\mathrm{f}}\right)$ and the rate of degradation (Table 8). The correlation has shown that the $\mathrm{K}_{\mathrm{f}}$ sorption coefficient is useful in predicting the degradation of the studied herbicides.

\section{Conclusion}

The sorption of herbicides increased in the order dimethenamid-p < pethoxamid < s-metolachlor < flurochloridone < aclonifen < pendimethalin. The largest $K_{f}$ values for all herbicides were obtained in Haplic Fluvisol. In general, there was a strong positive correlation between the adsorption coefficient and the OM content $(r \geq 0.981, p<0.001)$ and the CEC $(r \geq 0.974, p<0.001)$ for all herbicides. Moreover, the Freundlich isotherm (slope) $n$ values indicated a high affinity to the herbicides on all three soils, with only relatively little affinity to flurochloridone. The results concluded that the presence of a greater concentration of OM in soil may increase the adsorption of these herbicides. Degradation of herbicides was followed by first-order kinetics and increased in the order aclonifen < pethoxamid < dimethenamid-p < pendimethalin < flurochloridone < s-metolachlor. The dissipation half-lives of herbicides were significantly longer in Haplic Fluvisol (20-57 days) than compared to Arenic Regozem (17-51 days) and Haplic Chernozem (14-38 days). The degradation of herbicides is mainly controlled by clay and OM content. The longer half-lives were mainly found in soils with higher OM content. The influence of clay contents upon degradation was verified for pendimethalin, aclonifen, flurochloridone and s-metolachlor. The statistical correlations showed that herbicides pendimethalin, s-metolachlor, pethoxamid, and dimethenamid-p have negative effects on CEC and OM content. The soil pH did not correlate with the degradation rate of herbicides, except for pethoxamid. The linear regression and Pearson correlation test showed that the adsorption coefficient is most likely to play a significant role in predicting soil degradation of the studied herbicides.

\section{Declarations}

Conflict of interest

The authors have no affiliations with or involvement in any organization or entity with any financial interest or nonfinancial interest in the subject matter or materials discussed in this manuscript.

Author contributions

Umrbek Sharipov: Conceptualization, Methodology, Validation, Formal analysis, Investigation, Writing - original draft, Writing - review \& editing. Martin Kočárek: Conceptualization, Methodology, Validation, Investigation, Writing - review \& editing, Resources, Supervision. Miroslav Jursík: Project administration, Funding acquisition. Antonín Nikodém: Validation, Resources. Luboš Borůvka: Conceptualization, Supervision, Writing - review \& editing.

Acknowledgment

The study was funded by the Czech Ministry of Agriculture (QJ1510186) and the Czech University of Life Sciences Prague (SV16-10-21130). The authors would like to thank the Department of Soil Science and Soil Protection of the Czech University of Life Sciences in Prague for their support and cooperation. The language correction and improvement by Ing. Chris Ash, Ph.D. is also acknowledged.

\section{References}

1. Ainsworth CC, Frederickso JK, Smith SC (1993) Effect of sorption on the degradation of aromatic acids and bases. In: Linn DM, Ed., Sorption and Degradation of Pesticides and Organic Chemicals in Soil. SSSA Special Publication Vol. 32 Soil Sci Soc Am Inc; Madison, WI, pp. 125-144

2. Alletto L, Coquet Y, Benoit P, Bergheaud V (2006) Effects of temperature and water content on degradation of isoproturon in three soil profiles. Chemosphere 64: 1053-1061

3. Ahmad R, Nelson PN, Kookana RS (2006) The molecular composition of soil organic matter as determined by $13 \mathrm{C}$ NMR and elemental analyses and correlation with pesticide sorption. Eur. J. Soil Sci 57: 883-893

4. Ahmad M, Rajapaksha AU, Lim JE, Zhang M, Bolan N, Mohan D, Vithanage M, Lee SS, Ok YS (2014) Biochar as a sorbent for contaminant management in soil and water: a review. Chemosphere 99:19-33

Page 9/12 
5. Alletto L, Benoit P, Bolognesi B, Couffignal M, Bergheaud V, Dumeny V, Longueval Ch, Barriuso E (2013) Sorption and mineralisation of S-metolachlor in soils from fields cultivated with different conservation tillage systems. Soil Tillage Res 128: 97-103

6. Ben Hur M, Letey J, Farmer WJ, Williams CF, Nelson SD (2003) Soluble and solid organic matter effects on atrazine adsorption in cultivated soils. Soil Sci. Soc. Am. J 67: 1140-1146

7. Carringer RD, Weber JB, Monaco TJ (1975) Adsorption-desorption of selected pesticides by organic matter and montmorillonite. J Agric Food Chem 23:568-572

8. Dhareesank A, Kobazashi K, Usui K (2005) Phytotoxic activity of pethoxamid in soil under different moisture conditions. Weed Biol. Manag 5:197-202

9. EFSA (European Food Safety Authority) (2010) Conclusion on the peer review of the pesticide risk assessment of the active substance flurochloridone. EFSA J 8(12): 1869 (66 pp)

10. EFSA (European Food Safety Authority), Arena M, Auteri D, Barmaz S, Bellisai G, Brancato A et al. (2018) Conclusion on the peer review of the pesticide risk assessment of the active substance dimethenamid-p. EFSA J 16(4):5211 (40 pp)

11. Ferreira JA, Nascimento OR and Martin-Neto L (2001) Hydrophobic interactions between spin-label 5-SASL and humic acid as revealed by ESR spectroscopy. Environ Sci Technol 35: 761-765

12. Felsot AS, Dzantor EK (1995) Effect of alachlor concentration and an organic amendment on soil dehydrogenase activity and pesticide degradation rate. Environ. Toxicol. Chem 14:23-28

13. Gao JP, Maguhn J, Spitzauer P, Kettrup A (1998) Sorption of pesticides in the sediment of the Teufelsweiher pond (Southern Germany). II: Competitive adsorption, desorption of aged residues and effect of dissolved organic carbon. Water Resources 32(7): 2089-2094

14. Gouy V, Dur JC, Calvet R, Belamie R, Chaplain V (1999) Influence of adsorption-desorption phenomena on pesticide run-off from soil using simulated rainfall. Pestic. Sci 55: 175-182

15. Hermosin MC, Celis R, Carrizosa MJ, Ortega-Calvo JJ and Cornejo J (2006) Bioavailability of the herbicide 2,4-D formulated with organoclays. Soil Biol Biochem 38: 2117-2124

16. Hayes MHB (1970) Adsorption of triazine herbicides on soil organic matter, including a short review on soil organic matter chemistry. Residue Rev 32 : $131-174$

17. Hornsby AG, Wauchope RD, Herner AE (1996) Pesticide Properties in the Environment, Springer-Verlag, New York, Inc.

18. Hyun S, Lee LS and Rao PSC (2003) Significance of anion exchange in pentachlorophenol sorption by variable-charge soils. J Environ Qual 32: $966-976$

19. Jursík M, Soukup J, Holec J, Andr J, Hamouzová K (2015) Efficacy and selectivity of pre-emergent sunflower herbicides under different soil moisture conditions. Plant Protect. Sci 51:214-222

20. Kah M and Brown CD (2007) Prediction of adsorption of ionizable pesticides in soils. J. Agric. Food Chem 55(6): 2312-2322

21. Kodešová R, Kočárek M, Kodeš V, Drábek O, Kozák J, Hejtmánková K (2011) Pesticide adsorption in relation to soil properties and soil type distribution in regional scale, J. Hazard. Mater 186:540-550

22. Kah M, Brown CD (2006) Adsorption of ionisable pesticides in soils. Rev. Environ. Contam. Toxicol 188:149-218

23. Klíčová S, Šebánek J, Hudeová M, Vítková H, Vlašínová H (2002) The effect of fluridone and flurochloridone on the incidence of albinism in pea (Pisum sativum) and on the abscission of leaves of privet (Ligustrum vulgare). Rostlinná Výroba 48:255-260

24. Kočárek M, Kodešová R, Sharipov U, Jursík M (2018) Effect of adjuvant on pendimethalin and dimethenamid-p behaviour in soil. J. Hazard. Mater 354:266-274

25. Kočárek M, Artikov H, Voříšek K, Borůvka L (2016) Pendimethalin degradation in soil and its interaction with soil microorganisms. Soil Water Res 11:213219

26. Kodešová R, Vignozzi N, Rohošková M, Hájková T, Kočárek M, Pagliai M, Kozák J, Šimůnek J (2009) Impact of varying soil structure on transport processes in different diagnostic horizons of three soil types. J. Contam. Hydrol 104:107-125

27. Kodešová R, Kočárek M, Hajková T, Hýbler M, Drábek O, Kodeš V (2012) Chlorotoluron mobility in compost amended soil. Soil Tillage Res $118: 88-96$

28. Kan AT, Tomson MB (1990) Effect of pH, and concentration on the transport of naphtalene in saturated aquifer media. J Contam Hydrol 5:235-251

29. Koskinen WC, Cox L, Yen PY (2001) Changes in sorption/bioavailability of imidacloprid metabolites in soil with incubation time. Biol. Fert. Soils 33 : $546-$ 550

30. Mohan SV, Krishna MR, Muralikrishna P, Shailaja S, Sarma PN (2007) Solid phase bioremediation of pendimethalin in contaminated soil and evaluation of leaching potential. Bioresour. Technol 98: 2905-10

31. Munoz-Leoz B, Garbisu C, Charcosset JY, Sanchez-Perez J, Antiguedad I, Ruiz-Romera E (2013) Non-target effects of three formulated pesticides on microbiallymediated processes in a clay-loam soil. Sci. Total Environ 449:345-354

32. Marín-Benito JM, Andrades MS, Sánchez-Martín MJ, Rodríguez-Cruz MS (2012) Dissipation of fungicides in a vineyard soil amended with different spent mushroom substrates. J. Agric. Food Chem 60:6936-6945

33. OECD (2000) Guidelines for the testing of chemicals 106, Adsorption - Desorption Using a Batch Equilibrium Method, Paris, France.

34. OECD (2002) Guidelines for the testing of chemicals 307, Aerobic and Anaerobic Transformation in Soil. In: Degradation and Accumulation, Section 3, pp 17

35. Pose-Juan E, Marin-Benito JM, Sanchez-Martin MJ, Rodriguez-Cruz MS (2018) Dissipation of herbicides after repeated application in soils amended with green compost and sewage sludge. J. Environ. Manag 223:1068-1077

36. Peter CJ, Weber JB (1985) Adsorption, mobility and efficacy of alachlor and metolachlor as influenced by soil properties. Weed Sci 33(6):874-881

Page $10 / 12$ 
37. Pinna MV, Roggero PP, Seddaiu G, Pusino A (2014) Soil sorption and leaching of active ingredients of Lumax® under mineral or organic fertilization. Chemosphere 111:372-378

38. Quintero JC, Moreira MT, Feijoo G and Lema JM (2005) Effect of surfactants on the soil desorption of hexachlorocyclohexane (HCH) isomers and their anaerobic biodegradation. J Chem Technol Biot 80:1005-1015

39. Rao PSC, Mansell RS, Baldwin LB, Laurent MF (1983) Pesticides and their Behavior in Soil and Water. Soil Science Fact Sheer. Florida Cooperative Extension Service, Institute of Food and Agricultural Sciences, University of Florida.

40. Ramakrishna M, Mohan SV, Shailaja S, Narashima R, Sarma PN (2008) Identification of metabolites during biodegradation of pendimethalin in bioslurry reactor. J. Hazard. Mater 151: 658-661

41. Rytwo G, Gonen Y, Afuta S, Dultz S (2005) Interactions of pendimethalin with organo-montmorillonite complexes. Appl. Clay Sci 28:67-77

42. Rodriguez-Rubio P, Morillo, E and Maqueda C (2006) Sorption of 2,4-D on natural and organic amended soils of different characteristics. J Environ Sci Health Part B 41:145-157

43. Rodriguez-Cruz MS, Pose-Juan E, Marin-Benito JM, Igual JM, Sanchez-Martin MJ (2019) Pethoxamid dissipation and microbial activity and structure in an agricultural soil: Effect of herbicide rate and organic residues. Appl. Soil Ecol 140:135-143

44. Rice PJ, Anderson TA, Coats JR (2002) Degradation and persistence of metolachlor in soil: effects of concentration, soil moisture, soil depth, and sterilization. Environ. Toxicol. Chem 21(12):2640-2648

45. Stevenson FJ (1972) Organic matter reactions involving herbicides in soil. J. Environ. Qual 1:333-343

46. Spongberg J and Ganliang G (2000) Adsorption of atrazine and metolachlor in three soils from blue creek wetlands, Waterville, Ohio. Sci Soil 5:205-212

47. Spark KM, Swift RS (2002) Effect of soil composition and dissolved organic matter on pesticide sorption. Sci. Total Environ 298(1-3):147-161

48. Si Y, Takagi K, Iwasaki A, Zhou D (2009) Adsorption, desorption and dissipation of metolachlor in surface and subsurface soils. Pest Manag Sci 65:956962

49. Sakaliene O, Papiernik, S.K, Koskinen WC, Spokas KA (2007) Sorption and predicted mobility of herbicides in Baltic soils. J. Environ. Sci. Health B 42(6):641-647

50. Shetti NP, Malode ShJ, Vernekara PR, Nayak DS, Shetty NS, Reddy KR, Shukla ShS, Aminabhavi TM (2019) Electro-sensing base for herbicide aclonifen at graphitic carbon nitride modified carbon electrode - Water and soil sample analysis. Microchem J 149:103976

51. Selim HM, Ma L, Zhu H (1999) Predicting solute transport in soils: second-order two site models. Soil Sci. Soc. Am. J 63:768-777

52. Trevisan M, Capri E, Cella A, Errera G, Sicbaldi F (1999) Field, laboratory and modelling studies to evaluate aclonifen soil fate. Toxicol. Environ. Chem 70:29-47

53. University of Hertfordshire, PDB (accessed December 2019) Pesticide Properties Database, http://sitem.herts. ac.uk/aeru/ppdb/en/Reports/511.htm

54. Vischetti C, Marucchini C, Leita L, Cantone P, Danuso F, Giovanardi R (2002) Behaviour of two sunflower herbicides metobromuron and aclonifen. Euro. J. Agron 16:231-238

55. Vouzounis NA and Americanos PG (1995) Persistence of flurochloridone and terbutryn in soil. Technical Bulletin 173, Agricultural Research Institute, Nicosia. $14 \mathrm{p}$.

56. Villaverde J, Kah M and Brown DC (2008) Adsorption and degradation of four acidic herbicides in soils from southern Spain, Pest Manag Sci 64:703-710

57. Walker A, Jurado-Exposito M, Bending GD, Smith VJR (2001) Spatial variability in the degradation rate of isoproturon in soil. Environ. Pollut 111:407-415

58. Weber JB, Miller CT (1989) Organic chemical movement over and through soil. Reactions and movement of organic chemicals in soils. Soil Sci Soc Am Inc. Madison, USA pp. 305-334

59. Wu XM, Li M, Long YH, Liu RX, Yu YL, Fang H, Li SN (2011) Effects of adsorption on degradation and bioavailability of metolachlor in soil. J. Soil Sci. Plant Nutr 11:83-97

60. Weber JB, Wilkerson GG, Reinhardt CF (2004) Calculating pesticide sorption coefficients $\left(K_{d}\right)$ using selected soil properties. Chemosphere 55:157-166

61. Wauchope RD, Buttler TM, Hornsby AG, Augustijn Beckers PWM, Burt JP (1992) SCS/ARS/CES Pesticide properties database for environmental decision making. Rev. Environ.Contam. Toxicol 123:1-157

62. Westra EP, Shaner DL, Barbarick KA, Khosla R (2015) Evaluation of sorption coefficients for pyroxasulfone, s-metolachlor, and dimethenamid-p. Air, Soil Water 8:9-15

63. Weber JB, McKinnon EJ, Swain LR (2003) Sorption and mobility of C-14-labeled imazaquin and metolachlor in four soils as influenced by soil properties. J. Agric. Food Chem 51:5752-5759

64. Weber JB, Wilkerson GG, Michael Linker H et al. (2000) A proposal to standardize soil/solution herbicide distribution coefficients. Weed Sci 48:75-88

65. Walker A (1987) Evaluation of a stimulation model for prediction of herbicide movement and persistence in soil. Weed Res 27:143-152

\section{Figures}




\section{Image not available with this version}

Figure 1

The herbicides Freundlich sorption isotherms are presented in Figure 1

\section{Supplementary Files}

This is a list of supplementary files associated with this preprint. Click to download.

- Supplementarymaterial.docx 